\title{
Sequence analysis of immunoglobulin variable region genes that encode autoantibodies expressed by lymphomas of mucosa associated lymphoid tissue
}

\author{
C J Chapman, D K Dunn-Walters, F K Stevenson, T Hussell, P G Isaacson, \\ J Spencer
}

\begin{abstract}
Aim-To determine whether the immunoglobulin genes used by three gastric mucosa associated lymphoid tissue type lymphomas with known autoreactivity are mutated from germline as mutation from germline is an indicator of exposure to a mutational mechanism which characteristically acts on $B$ cells as they undergo a follicle centre response.

Methods-Cell lines established from two cases of MALT type lymphoma secrete autoantibodies recognising follicular dendritic cells (one case) and basement membrane (one case). The immunoglobulin heavy chain variable region genes $\left(\mathrm{IgV}_{\mathrm{H}}\right)$ and light chain variable region genes $\left(\operatorname{IgV}_{\mathrm{L}}\right)$ used by these cell lines, and the $I V_{H}$ genes from a third case recognising human IgG were sequenced.

Results-All three cases studied had mutated $\operatorname{IgV}_{\mathrm{H}}$ genes, while the $\operatorname{IgV}_{\mathrm{L}}$ genes were unmutated.

Conclusion-The presence of mutations in $\operatorname{IgV}_{\mathrm{H}}$ genes is consistent with the origin of gastric MALT type lymphomas from $B$ cells which have traversed the lymphoid follicle.
\end{abstract}

(f Clin Pathol: Mol Pathol 1996;49:M29-M32)

Keywords: mucosa associated lymphoid tissue type lymphoma, gastric lymphoma, mutation.

Department of

Histopathology,

UCL Medical School,

University Street

London

D K Dunn-Walters

$T$ Hussell

P G Isaacson

J Spencer

Molecular

Immunology Group,

Tenovus Laboratory,

Tremona Road,

Southampton

C J Chapman

F K Stevenson

Correspondence to:

Correspondence to:

of Histopathology,

of Histopathology,

Rockefeller Building,

London WC1E 6JJ.

Accepted for publication

31 October 1995

Gastric lymphomas of mucosa associated lymphoid tissue (MALT) type may be dependent on the spiral bacterium Helicobacter pylori for growth as eradication of the bacteria results in regression of lymphoma in many cases. ${ }^{1}$ However, the immunoglobulin expressed by the tumour cells in four cases studied to date recognises single, distinct autoantigens and does not cross react with $H$ pylori. ${ }^{23}$ The four published cases recognise an epitope associated with IgA and IgM, ${ }^{2}$ follicular dendritic cells, ${ }^{3}$ a basement membrane component, ${ }^{3}$ and IgG (unpublished observations). ${ }^{3}$ The recognition of distinct autoantigens in each case reported suggests that reactivity with autoantigens may be a significant factor in the pathogenesis of gastric MALT type lymphomas.
Low grade B cell MALT type lymphomas are thought to be malignancies of marginal zone B cells which surround the mantle zone in normal human spleen and Peyer's patches. ${ }^{4}$ Consistent with the phenotype of marginal zone B cells, MALT type lymphomas are predominantly $\mathrm{CD} 5-, \operatorname{Ig} M+, \operatorname{IgD}-$, although cases expressing other immunoglobulin isotypes have been observed. ${ }^{5}$ Most normal human marginal zone $B$ cells have mutated immunoglobulin heavy chain variable region $\left(\operatorname{IgV} \mathrm{H}_{\mathrm{H}}\right)$ genes. ${ }^{6}$ Mutations in $\mathrm{IgV}_{\mathrm{H}}$ genes are characteristically acquired as B cells undergo a follicle centre response during the process of affinity maturation. ${ }^{7}$ In the course of this process in the follicle centre, $\mathrm{B}$ cells with mutations in their $\mathrm{IgV}_{\mathrm{H}}$ genes that result in an increase in the affinity of the encoded immunoglobulin for antigen are expanded, whereas B cells which acquire mutations resulting in loss of affinity are deleted. It is likely, therefore, that normal human marginal zone B cells have been though a follicle centre and may be memory $B$ cells. This is consistent with a study showing that in rats memory $\mathrm{B}$ cells colonise the marginal zone. ${ }^{8}$ The aim of this study was to determine whether the immunoglobulin genes used by three gastric MALT type lymphomas with known autoreactivity ${ }^{3}$ are mutated from germline. If so, this would suggest that these lymphomas are derived from $B$ cells which have been through a follicle centre response.

\section{Methods}

CELL LINES AND TISSUES

The immunoglobulin genes used by three cases of low grade B cell gastric lymphoma of MALT type were analysed. Heterohybridoma cell lines produced by fusing cells from cases 1 and 2 with murine hybridoma cell line NSO were characterised in a previous study. ${ }^{3}$ The heterohybrid clone derived from case 1 (F.26) secreted tumour derived $\operatorname{IgM} \kappa$, recognising follicular dendritic cells. ${ }^{3}$ The clone from case 2 (C.26) secreted $\operatorname{Ig} M \lambda$, recognising a venular basement membrane component ${ }^{3}$. These cell lines were used as a source of RNA for this study. The tissue used for the study of case 3 (IgM $\kappa$, recognising IgG) (unpublished observations) ${ }^{3}$ was received fresh and was snap frozen in liquid nitrogen and stored at $-70^{\circ} \mathrm{C}$ until required. 
4.30 CGG CTG CAG CTG CAG GAG TCG GGC CCA GGA CTG GTG AAG CCT TCG GAG ACC CTG TCC CTC ACC F.26 .A. $\ldots . . .$.

4.30 TGC ACT GTC TCT GGT GGC TCC ATC AGC AGT AGT AGT TAC TAC TGG GGC TGG ATC CGC CAG CCC

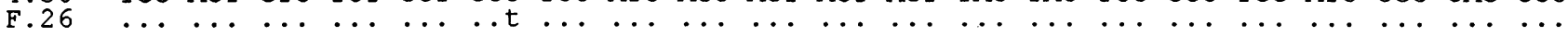

4.30 CCA GGG AAG GGG CTG GAG TGG ATT GGG AGT ATC TAT TAT AGT GGG AGC ACC TAC TAC AAC CCG

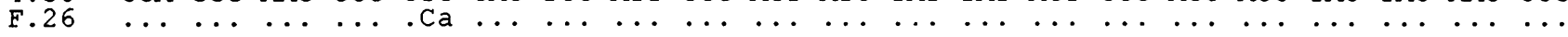
$0 .-\cdots-1-\cdots-1$

4.30 TCC CTC AAG AGT CGA GTC ACC ATA TCA GTA GAC ACG TCC AAG AAC CAG TTC CCC CTG AAG CTG

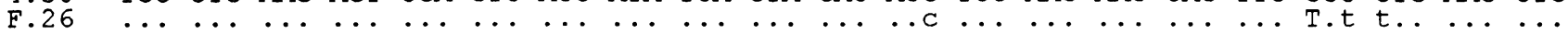

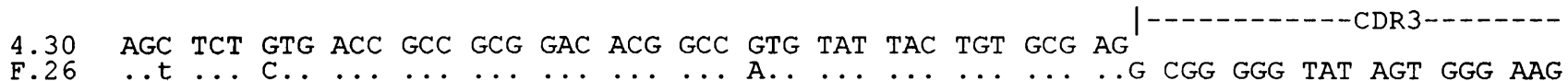
$\begin{array}{lllllllllllll}\text { JH5b } & & & \end{array}$

B

DP38 GAG GTG CAG CTG GTG GAG TCT GGG GGA GGC TTG GTA AAG CCT GGG GGG TCC CTT AGA CTC TCC

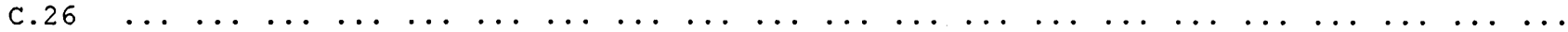

DP38 TGT GCA GCC TCT GGA TTC ACT TTC AGT AAC GCC TGG ATG AGC TGG GTC CGC CAG GCT CCA GGG

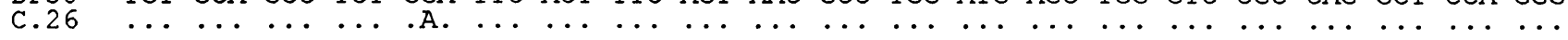
DP38 AAG GGG CTG GAG TGG GTT GGC CGT ATT AAA AGC AAA ACT GAT GGT GGG ACA ACA GAC TAC GCT

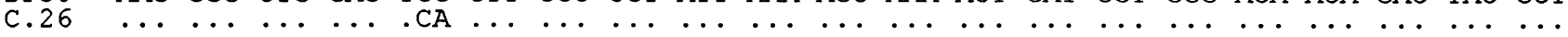
DP38 GCA CCC GTG AAA GGC AGA TTC ACC ATC TCA AGA GAT GAT TCA AAA AAC ACG CTG TAT CTG CAA C.26 C.

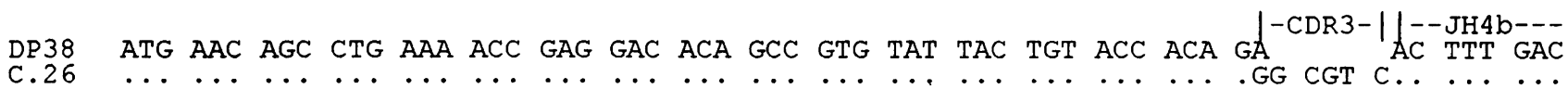
JH4b TAC TGG GGC CAG GGA ACC CTG GTC ACC GTC TCC TCA GTC TCC TCA

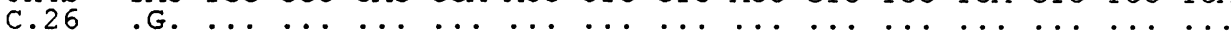

C DP32 GAG GTG CAG CTG GTG GAG TCT GGG GGA GGT GTG GTA CGG CCT GGG GGG TCC CTG AGA CTC TCC

DP32 TGT GCA GCC TCT GGA TTC ACC TTT GAT GAT TAT GGC ATG AGC TGG GTC CGC CAA GCT CCA GGG

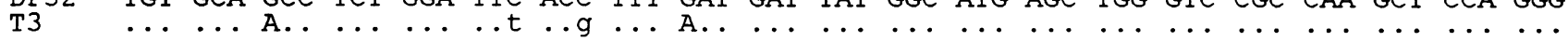

DP32 AAG GGG CTG GAG TGG GTC TCT GGT ATT AAT TGG AAT GGT GGT AGC ACA GGT TAT GCA GAC TCT

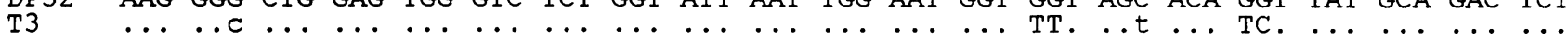
DP32 GTG AAG GGC CGA TTC ACC ATC TCC AGA GAC AAC GCC AAG AAC TCC CTG TAT CTG CAA ATG AAC

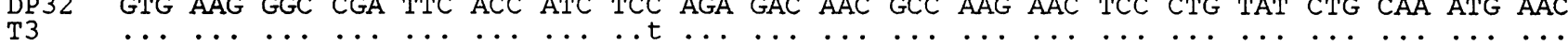

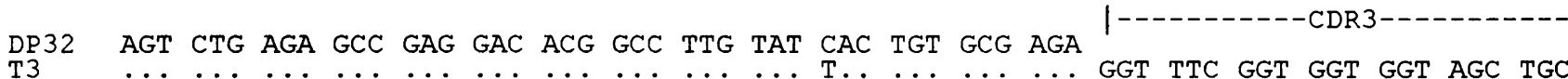
JH6

T3 TAC TCC AAT GGG TG. $\ldots \ldots \ldots \ldots$

Comparison of $V_{\mathrm{H}}-\mathcal{F}_{\mathrm{H}}$ sequences derived from $(A)$ case $1,(B)$ case 2 and $(C)$ case 3 with closest match germline sequences. Replacement mutations are shown in upper case; silent mutations in lower case. In case 3 no sequence data were available for codons 1-21 of IgV $V_{\mathrm{H}}$ or the $3^{\prime}$ end of $\mathfrak{F}_{\mathrm{H}}$ because of the positions of the primers used. All sequences are mutated.

ANALYSIS OF CDNA SEQUENCE IN CASES 1 AND 2 RNA from cell lines F.26 and C.26 was isolated and reverse transcribed as described previously. ${ }^{9}$ The $\operatorname{IgV}_{\mathrm{H}}$ genes were amplified by PCR using $V_{H}$ leader region primers ${ }^{10}$ and a $\mathrm{C} \mu$ constant region primer ${ }^{11}$ under conditions described previously. At least two independent PCR products were purified and sequenced directly as described by Chapman et al. ${ }^{12} \mathrm{~V}_{\mathrm{L}}$ genes were amplified using a mixture of primers specific for framework region 1 and $\mathrm{J}_{\mathrm{H}} \cdot{ }^{13} \mathrm{PCR}$ products were purified by gel electrophoresis and subcloned into the TA vector (Promega, Madison, Wisconsin, USA). At least six clones from two independent PCR reactions were analysed. Sequence analysis was performed 
using MacVector 4.0 software (IBI, New Haven, Connecticut, USA) and alignment made to EMBL and V-BASE databases. ${ }^{14}$

ANALYSIS OF DNA SEQUENCE FROM CASE 3

As a cell line was not available for case 3, genomic DNA sequences were analysed. DNA was isolated from $7 \mu \mathrm{m}$ sections of frozen tissue, immunohistochemically stained using an antiidiotypic antibody to identify the tumour cells as described by Hussell et al. ${ }^{3} \mathrm{~V}_{\mathrm{H}}$ genes, from $\mathrm{V}_{\mathrm{H}}$ framework region 1 region to $\mathrm{J}_{\mathrm{H}}$, were amplified using a nested PCR technique and cloned into the vector pCR-Script $\mathrm{SK}(+)$ as described previously. ${ }^{6}$ Clone inserts were amplified using T3 and T7 primers under standard conditions. PCR reaction conditions comprised 30 cycles with an annealing temperature of $45^{\circ} \mathrm{C}$. Prior to sequencing, $5 \mu \mathrm{l}$ of the PCR products was treated sequentially with exonuclease 1 and shrimp alkaline phosphatase, and sequenced using the Sequenase PCR product sequencing kit (Amersham International, Little Chalfont, UK). Sequence analysis was carried out using Wisconsin GCG software and V-BASE. Germline matches were made using the EMBL database.

\section{Results}

CASE

The immunoglobulin heavy chain used by the F.26 cell line, which secreted the immunoglobulin from case 1 , used $\mathrm{V}_{\mathrm{H}} 4.30$ and $\mathrm{J}_{\mathrm{H}} 5 \mathrm{~b}$ (figure, panel A). This sequence has 13 mutations (five replacement and eight silent) compared with the published germline sequences of $\mathrm{V}_{\mathrm{H}} 4.30$ and $\mathrm{J}_{\mathrm{H}} 5 \mathrm{~b}$. All mutations in $\mathrm{V}_{\mathrm{H}}$ were situated in the framework region. One silent mutation was situated in $\mathrm{J}_{\mathrm{H}}$. The light chain from this immunoglobulin molecule was a precise germline match to $\mathrm{Vk} 02 / 012 / \mathrm{DPK}, \mathrm{Jk} 1$.

CASE 2

The immunoglobulin heavy chain used by the C.26 cell line, which was derived from the tumour cells in case 2 , used the $\mathrm{V}_{\mathrm{H}} 3$ family member DP38 and $\mathrm{J}_{\mathrm{H}} 4 \mathrm{~b}$ (figure, panel B). The sequence was mutated from the published germline sequence, with four replacement mutations in $\mathrm{V}_{\mathrm{H}}$ and one in $\mathrm{J}_{\mathrm{H}}$. Of the four mutations in $\mathrm{V}_{\mathrm{H}}$, three were in the framework region. The light chain used by case 2 was an exact match to germline $\lambda$ chain gene LV801.

CASE 3

The same heavy chain sequence was obtained in five of six clones sequenced using DNA from case 3. This sequence was in frame in CDR3 and contained no stop codons and was therefore thought to be the allele used by the tumour cells. The $\operatorname{IgV}_{\mathrm{H}} \mathrm{DP} 32\left(\mathrm{~V}_{\mathrm{H}} 3\right.$ family) is associated with $\mathrm{J}_{\mathrm{H}} 6$. This sequence has 12 mutations compared with the published germline sequence (seven replacement and five silent) (figure, panel C). Four replacement mutations occurred in the framework region and three in the complementarity determining regions.

\section{Discussion}

All of the $\operatorname{IgV}_{\mathrm{H}}$ genes sequenced are mutated when compared with the closest match germline sequences. This suggests that the $\operatorname{IgV}_{\mathrm{H}}$ genes have been exposed to the mutational mechanism, which is characteristically active in the germinal centre. ${ }^{7}$ This is consistent with the origin of MALT type lymphomas from marginal zone B cells, which also harbour mutated immunoglobulin genes, suggesting that they are post-follicular. ${ }^{6}$ Although the databases from which the matched germline sequences were derived are considered to represent the complete repertoire, we cannot exclude the possibility that some apparent mutations are due to polymorphic variation. However, this is unlikely to account for all of the variation observed. The base changes were observed in repeat sequences and therefore were not due to PCR error. In addition, the presence of mutations in $\mathrm{J}_{\mathrm{H}}$ in cases 1 and 2 would be unusual if the $\mathrm{V}_{\mathrm{H}}$ were unmutated.

The processes involved in the removal of B cells recognising autoantigen is not clearly understood. However, it has been shown that B cells with specificity for soluble antigens die when then they bind soluble autoantigen in the germinal centre. ${ }^{1516}$ This group of soluble antigens could theoretically include IgG, the autoantigen recognised by case 3 . The hypothesis that B cells recognising soluble antigens are eliminated in the follicle centre is supported by the analysis of $\operatorname{IgV}_{\mathrm{H}}$ genes used by postimmunisation rheumatoid factors. This analysis provides evidence for the deletion of putative high affinity mutated variants. ${ }^{17}$ The autoreactivity observed in the cases of MALT type lymphoma studied herein suggests that the postfollicular precursors of these lymphomas were unresponsive to, or were not subjected to, such a process of deletion in the germinal centre. They may have been able to avoid deletion through neoplastic transformation.

Immunoglobulin derived from MALT type lymphomas differs from the polyreactive immunoglobulin expressed by cases of chronic lymphocytic leukaemia. The former is produced by mutated $\operatorname{IgV}_{\mathrm{H}}$ genes and recognises single autoantigens. The latter, however, is encoded mostly, but not exclusively, by germline $\mathrm{IgV}_{\mathrm{H}}$ genes. ${ }^{18}$ This autoreactivity seems to have a different aetiology in these different lymphoma groups. The frequency with which autoreactivity is associated with lymphoma suggests that cross-linking of tumour derived immunoglobulin by autoantigen may be a significant factor in the pathogenesis of lymphoma.

We are grateful to $C$ Ian Mockridge for help with the sequencing. This work was supported by Tenovus and the Wessex Medical Trust (CJC), he Cancer Research Campaign (TH).

1 Wotherspoon AC, Doglioni C, Diss TC, Pan L, Moschini $A$, de Boni $M$, et al. Regression of primary low-grade BA, de Bonic AC cell gastric lymphoma of mucosa-associated lymphoid 1993;342:575-7.

2 Greiner A, Marx A, Heesman J, Leebman J, Schmausser 
B, Muller-Hermelink HK. Idiotype identity in a MALTtype lymphoma and B cells in Helicobacter pylori associated chronic gastritis. Lab Invest 1994;70:572-8.

3 Hussell T, Isaacson PG, Crabtree JE, Dogan A, Spencer J. Immunoglobulin specificity of low grade B cell gastrointestinal lymphoma of mucosa-associated lymphoid tissue (MALT) type. Am f Pathol 1993;142:285-92.

4 Spencer J, Finn T, Pulford KAF, Mason DY, Isaacson PG. The human gut contains a novel population of $B$ PG. The human gut contains a novel population of B lymphocytes which resemble ma

5 Isaacson PG, Spencer J, Finn T. Primary B cell gastric lymphoma. Hum Pathol 1986;17:72-82.

6 Dunn-Walters DK, Isaacson PG, Spencer J. Analysis of mutations in $\mathrm{IgV}_{\mathrm{H}}$ genes of microdissected marginal zone $B$ cells suggests that the marginal zone of human spleen is a reservoir of memory B cells. F Exp Med 1995;182: 559-66.

7 Jacob J, Kelsoe G, Rajewsky K, Weiss U. Intraclonal generation of antibody mutants in germinal centres. Nature 1991:354:389-92.

8 Liu YJ, Oldfield S, MacLennan ICM. Memory B cells in $T$ cell-dependent antibody responses colonize the splenic marginal zones. Eur F Immunol 1988;18:355-62.

9 Chapman CJ, Mockridge CI, Rowe M, Rickinson AB, Stevenson FK. Analysis of $\mathrm{V}_{\mathrm{H}}$ genes used by neoplastic B cells in endemic Burkitt's lymphoma shows somatic hypermutation and intraclonal heterogeneity. Blood 1995; 85:2176-81.

10 Campbell MJ, Zelenetz AD, Levy S, Levy R. Use of family specific leader region primers for PCR amplification of the human heavy chain variable region gene repertoire. Mol Immunol 1992;29:193-203.

11 Silberstein LE, Jeffries LC, Goldman J, Friedman D, Moore IS, Nowell PC, et al. Variable region gene analysis of pathologic human autoantibodies to the related $\mathrm{i}$ and $\mathrm{I}$ red blood cell antigens. Blood 1991;78:2372-86.

12 Chapman CJ, Spellerberg MB, Smith GA, Carter SJ, Hamblin TJ, Stevenson FK. Auto anti-red cell antibodies ize the $V_{11} 4.21$ gene segment. F Immumol 1993;151:1051 61 .

13 Marks JD, Tristem M, Karpas A, Winter G. Oligonucleotide primers for PCR amplification of human immunoglobulin variable genes and design of family specific oligonucleotide probes. Eur f Immunol 1991;21:985-91.

14 Cook GP, Tomlinson IM. The human immunoglobulin $\mathrm{V}_{1}$ repertoire. Immunol Today 1995;16:237-41

15 Pulendran B, Kannourakis G, Nouri S, Smith KGC, Nossal GJV Soluble antigen can cause apoptosis of germinal centre B cells. Nature 1995;375:331-4

16 Shokat KM, Goodnow CC. Antigen induced B-cell death and elimination during germinal-centre immune reand elimination during germinat

17 Borretzen M, Randen I, Zdarsky E, Forre O, Natvig JB Thompson KM. Control of autoantibody affinity by selection against amino acid replacements in the complementarity-determining regions. Proc Natl Acad Sci USA 1994;91:12917-21.

18 Casali P, Notkins AL. CD $5+$ B lymphocytes, polyreactive antibodies and the human B-cell repertoire. Immunol Today 1989;10:364-8. 